\title{
INSTRUMENTALIST LOGIC OF SCIENTIFIC DISCOVERY: REFLECTIONS ON DEWEY'S METHOD AND ITS METAPHYSICAL FOUNDATIONS
}

\begin{abstract}
Andrii Leonov
Abstract. In this paper, I attempt to clarify the heart of Dewey's philosophy: his method (denotative method (DM) / pattern of inquiry (PI)). Despite the traditional understanding of Dewey as anti-foundationalist, I want to show that Dewey did have metaphysical foundations for his method: the principle of continuity or theory of emergentism. I also argue that Dewey's metaphysical position is better named as 'cultural emergentism', rather than his own term 'cultural naturalism'. What Dewey called 'common sense' in his Logic, Husserl termed as the 'life-world' in his Crisis. I compare two perspectives of dealing with the phenomenon and conclude that for Dewey, the difference between natural sciences and the common sense inquiry is that of subject-matter but not of method. Thus, the goal is to find the unified method to be applied in both domains. Whereas Husserl was more pessimistic: for him, the difference was not only in subject-matter, but in the very methods. Following that discussion, I also attempt to reformulate the hard problem of consciousness in Deweyan terms. In the end, I compare Dewey's DM / PI with Popper's understandings of scientific method and conclude that there is no significant difference between the two and that Dewey's method could also be looked at as hypothetic-deductive method, with the only difference in emphases.
\end{abstract}

Keywords: instrumentalist / experimental logic, denotative method, pattern of inquiry, principle of continuity, emergentism, experience, problematic situation, common sense, life-world, hard problem of consciousness, fact, hypothesis, Dewey, Husserl, Popper.

\section{ІНСТРУМЕНТАЛІСТСЬКА ЛОГІКА НАУКОВОГО ВІДКРИТТЯ: РОЗДУМИ ПРО МЕТОД ДЬЮЇ ТА ЙОГО МЕТАФІЗИЧНІ ОСНОВИ}

\footnotetext{
Анотація. У цій роботі я намагаюся прояснити сутність філософії Дьюї: його метод (денотативний метод (ДМ) / структуру дослідження (СД)). Незважаючи на традиційне розуміння Дьюї як анти-фундаменталіста, я хочу показати, що, насправді, його метод мав метафізичні основи: приниил
} 
тяглості або теорію емерджентизму. Я також обгрунтовую, що метафізичну позицію Дьюї краще називати «культурним емерджентизмом», аніж його терміном «культурний натуралізм». Те, що Дьюї називав «здоровим глуздом» у своїй «Логіці», Гуссерль позначав терміном «життєвий світ» $\mathrm{y}$ «Кризі». Я порівнюю два погляди на розуміння цього явища і роблю висновок, що для Дьюї різниця між природничими науками та здоровим глуздом полягає у предметі, а не в методі. Отже, мета полягає у тому, щоб знайти уніфікований метод, який застосовуватиметься в обох сферах. Тоді як Гуссерль був більш песимістичним: для нього різниця полягала не тільки в предметі, а й у самих методах. Услід за цим обговоренням, я також зробив спробу переформулювати важку проблему свідомості у термінах Дьюї. Насамкінець, я порівнюю ДМ / СД Дьюї з попперівським розумінням наукового методу і роблю висновок, що між ними немає значної різниці, і що метод Дьюї також можна розглядати як аinomemuкодедуктивний, з єдиною різницею в акцентах.

Ключові слова: інструменталістська / експериментальна логіка, денотативний метод, структура дослідження, принцип тяглості, емерджентизм, досвід, проблемна ситуація, здоровий глузд, життєвий світ, важка проблема свідомості, факт, гіпотеза, Дьюї, Гуссерль, Поппер.

The position which I take, namely, that all knowledge, or warranted assertion, depends upon inquiry and that inquiry is, truistically, connected with what is questionable (and questioned) involves a skeptical element, or what Peirce called 'fallibilism'. But it also provides for probability, and for determination of degrees of probability in rejecting all intrinsically dogmatic statements, where 'dogmatic' applies to any statement asserted to possess inherent self-evident truth. That the only alternative to ascribing to some propositions self-sufficient, self-possessed, and self-evident truth is a theory which finds the test and mark of truth in consequences of some sort is, I hope, an acceptable view. At all events, it is a position to be kept in mind in assessing my views [9, p. 203].

\section{Introduction}

What is the heart of Dewey's philosophy? It is hard even to try to answer such a question given such a prolific author as Dewey. Nevertheless, one can argue that it is his aesthetics, metaphysics, his theory of education, ethics etc., because Dewey seemed to apply his central philosophical insights in every major area of philosophical research.

Here, I want to look at Dewey as a philosopher of science in the first place. In my view, the quintessence of Dewey's philosophy is his philosophic method. Because namely his method as applied in the philosophic areas as above-mentioned exemplified Dewey's original voice as a philosopher Dewey as he is known today.

It's not hard to see that Dewey's method of any kind of investigation or inquiry should be understood as the 'pattern of inquiry' (PI), as well 
as the 'denotative method' (DM). The former was well exemplified in his monumental Logic (1938) [8], whereas the latter is to be discovered in his metaphysical magnum opus Experience and Nature (1925) [7]. But, generally speaking, the very pattern or the 'essence' of the method can be found in every Dewey's work, which shows his experimental logic. Namely, the method of inquiry exemplifies the structure of experience as such. And no one could have possibly denied that the notion of experience is one of the key concepts (if not the most important one) in Dewey's philosophy.

I also believe that Dewey's DM / PI is how Dewey himself understood the method of natural sciences. The latter he took as an example of the successful inquiry, essentially experimental, and always subject to change and thus, to progress. In his Reconstruction of Philosophy [6], Dewey was explicit that philosophy should be oriented toward the natural sciences, while in his Logic he explained that this should be just an orientation and in no way a reduction. Therefore, Dewey was against the reduction of philosophy to the natural sciences, but the success of natural sciences made him interested in the natural scientific method and a strong proponent of the implementation of that method into philosophic inquiry. That allows Dewey to identify his position as naturalism, but not as physicalism or materialism ${ }^{1}$. The latter seems to be impossible since Dewey was against any metaphysical standpoint as a beginning of inquiry. But nevertheless, it is more complicated than it seems prima facie. It seems that Dewey does have a metaphysical principle as the foundation of inquiry, which he calls a 'principle of continuity': we are continuous as well as interdependent with nature. To put it briefly, the latter principle exemplifies what today could be called a theory of emergentism. According to this theory, consciousness or mind emerge from the physical at some point, but is not reducible to it. But here is the crucial question: what does actually emerge according to Dewey? This is also a question to be dealt with.

Therefore, Dewey's naturalism as well as the theory of inquiry has a two-fold origin: one in terms of method, and the other one - as regards to its foundations. As to the latter, this is a 'principle of continuity' or emergentism. I would even argue that Dewey's metaphysical philosophy could be claimed as 'cultural emergentism' rather than 'cultural naturalism' (as it is originally put by Dewey himself) [8, p. 28].

It is interesting to mention that Dewey's pattern of inquiry has a unifying force: it is to be applied in both natural sciences as well as at the

\footnotetext{
${ }^{1}$ In his 1943 paper Anti-Naturalism in Extremis, Dewey was explicitly defending his naturalistic position against materialistic interpretations [10].
} 
common sense level. Namely, common sense (as depicted in Dewey's Logic) is what Edmund Husserl would earlier call in his Crisis of the European Sciences (1935) as the life-world (das Lebenswelt). But as opposed to Husserl, and given Dewey's naturalistic origins and inclination, his tone was more optimistic: the pattern of inquiry is to unite both common sense and the natural sciences, and given that the very method is to be derived from that of the natural sciences, there is no reason to talk about a totally different methodology to properly deal with the common sense level in the first place. It is enough to grasp the very method of the sciences and employ it at the common sense level as well.

But before talking about inquiry's pattern, let's look at Dewey's understanding of inquiry itself.

\section{Inquiry and its metaphysical foundations: Dewey's philosophy of mind}

Dewey seems to broadly identify logic with the theory of inquiry in general. By the latter, he understands «controlled or directed transformation of an indeterminate situation into one that is so determinate in its constituent distinctions and relations as to convert the elements of the original situation into a unified whole» [8, p. 108]. Where by 'situation', Dewey understands the objects and events in their connection with a 'contextual whole'. Namely, the latter signifies situation in a Deweyan sense [8, p. 108].

That being said, what are the metaphysical foundations of logic / theory of inquiry? One can look at the theory of emergentism as the metaphysical foundation in question. One has to note that Dewey didn't use the notion of emergentism as such, rather he constantly appealed to the principle of continuity. But the way he used this principle and defined its meaning definitely suggests that emergentism is the proper word to use here.

The general definition of emergentism is as follows:

$$
\begin{aligned}
& \text { emergent entities (properties or substances) 'arise' out of more fundamen- } \\
& \text { tal entities and yet are 'novel' or 'irreducible' with respect to them. (For } \\
& \text { example, it is sometimes said that consciousness is an emergent property } \\
& \text { of the brain.) [16]. }
\end{aligned}
$$

And Dewey's way of an appeal to continuity seems to be identical to the former definition: stating that logic is essentially naturalistic, Dewey means that «there is no breach of continuity between operations of inquiry and 
biological operations and physical operations. 'Continuity', on the other side, means that rational operations grow out of organic activities, without being identical with that from which they emerge» $[8$, p. 26].

The primary postulate of a naturalistic theory of logic is continuity of the lower (less complex) and the higher (more complex) activities and forms. The idea of continuity is not self-explanatory. But its meaning excludes complete rupture on one side and mere repetition of identities on the other; it precludes reduction of the 'higher' to the 'lower' just as it precludes complete breaks and gaps. The growth and development of any living organism from seed to maturity illustrates the meaning of continuity [8, p. 30].

On the one hand, and as it was shown before, the principle of continuity (or emergentism) is foundational for the theory of inquiry as such. On the other hand, Dewey is highly opposed to any logical first principles like 'a priori intuitional act' and 'Intellectus Purus' or Pure Intuition as foundation of logic and thus

\begin{abstract}
precludes resting logic upon metaphysical and epistemological assumptions and presuppositions. The latter are to be determined, if at all, by means of what is disclosed as the outcome of inquiry ${ }^{2}$; they are not to be shoved under inquiry as its «foundation». On the epistemological side, it precludes, as was noted earlier in another connection, the assumption of a prior ready-made definition of knowledge which determines the character of inquiry. Knowledge is to be defined in terms of inquiry, not vice-versa, both in particular and universally [8, p. 28].
\end{abstract}

That being said, one can see a contradiction: on the one hand, Dewey is trying to get rid of all metaphysical and epistemological assumptions and prejudices, but actually fails to do it because of his naturalism (emergentism). One can even suggest that Dewey tends to be 'phenomenologically-transcendental', without really being as $\operatorname{such}^{3}$.

As regards Dewey's philosophy of mind, the picture is different in that he doesn't seem to have any theory of 'mind' in general. Otherwise, in the chapter The Pattern of Inquiry from his Logic (1938), Dewey seems to present his behavioristic inclinations: he wants to get rid of anything 'mentalistic', 'subjective', 'mental' as opposed to 'publicly observable'. We are not mental creatures, but 'biological-cultural human beings' [8, p. 110].

\footnotetext{
${ }^{2}$ Italics are mine, Leonov A.

${ }^{3}$ On the other hand, one could say that though he failed in being transcendental in terms of neutrality to all metaphysical and epistemological presuppositions, he nevertheless succeeded in providing the essential conditions for any genuine method of inquiry as such: his denotative method / pattern of inquiry. In this sense, he does appear to be 'transcendental'.
} 
In the earlier chapters of his Logic, instead of emergence of a mind, Dewey talks about emergence of a 'life-behavior' or 'organic-behavior'. Though, Dewey still identifies an organism with a 'self', later on in his essay Anti-Naturalism in Extremis (1943) his radicalism goes even further: he wants to eradicate words like «mind, subject, self, person, the individual» as notions, which «absorbed from beliefs of an extra-natural character» $[10$, p. 164]. On the other hand, Dewey accepts the Kantian formula that «apart from each other 'perceptions are blind and conceptions empty'», where instead of a «third activity, that of synthetic understanding, to bring them together [...] perceptual and conceptual materials are in a functional correlativity with each other» $[8, \mathrm{p} .115]$. The facts should «be taken as representative and not just pre-sented» [8, p. 118].

On and on, Dewey emphasizes the 'life-behavior' as opposed to any 'mentalistic' concepts of mind, consciousness etc.

Schematically, Dewey's emergentism can be seen in the following way:

1) physical $\leftrightarrows \quad 2)$ biological

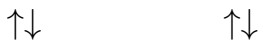

4) cultural $\rightleftarrows 3$ ) life / organic-behavior

As one can see, there is nothing mental in this scheme ${ }^{5}$. From this it follows, that Dewey's approach to the 'mind' is third-person, rather than first-person. ${ }^{6}$ And the theory of inquiry as such emerged from and is dependent upon all of these ontological layers, without being reduced to any of them, due to the emergentist principle of continuity.

That being said, maybe it would be better to call Dewey's philosophy not 'cultural naturalism', but 'cultural emergentism'. That would clarify his philosophical position much more, as well as free it from materialistic interpretations. What emerges from our organic interactions with the environment? Life or organic behavior (and not self, mind, subjectivity, person etc.) Thus, due to this fact, his emergentism has definitely some behavioristic inclinations. And because of his taking of the third-person perspective and his rejection the first-person perspective in general, the

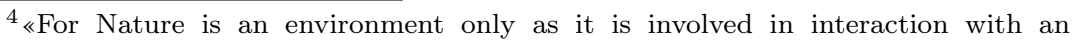
organism, or self, or whatever be used. [...] Except of course a purely mentalistic name like consciousness» [8, p. 28].

${ }^{5}$ In his Experience and Nature, Dewey names his view as an «'emergent' theory of $\operatorname{mind} \gg[7$, p. 207].

${ }^{6}$ Here, Dewey is really radical: «Personally, as has just been said, I doubt the existence of anything 'mental' in the doctrinal sense alleged» [8, p. 43].
} 
physicalist interpretation of Dewey's philosophy of mind is, unfortunately, more than suggestive.

According to the 'postulate of naturalistic continuity', and since «inquiry is a development out of organic environmental integration and interaction» $[8$, p. 42$]$ the pattern of inquiry emerged from our life-activities as well. For Dewey, this pattern is so significant that it could be applied in both common-sense and natural scientific levels.

A Reflection on common sense and natural sciences: Dewey's depiction vs Husserl's. In his Crisis of the European Sciences and Transcendental Phenomenology, Husserl proclaimed that basically there are two crises:

(1) crisis between transcendental phenomenology and the natural sciences (physicalism);

(2) and crisis between the natural sciences and the life-world (das Lebenswelt).

As shown in [14], «the opposition between the natural sciences (physicalism) and transcendental phenomenology [...] stems from the Cartesian metaphysics of res cogitans and res extensa (namely, from what I call the 'conceptual' mind-body problem) and thus, is the 'crisis' within the Cartesian framework, as well as of the latter» [14, p. 93].

Therefore, here I want to compare Husserl's and Dewey's takes on the (2) crisis: namely the gap between the life-world and the natural sciences.

The problem. First, one has to mention that what Husserl in his Crisis calls the life-world, Dewey, in his Logic, calls the common sense. Both notions refer to the same day-to-day experience, which is prescientific. In general, one wouldn't be mistaken to say that both $\mathrm{CS} / \mathrm{LW}^{7}$ refer to the world of quality, when the scientific realm is that of quantity ${ }^{8}$.

Both Husserl and Dewey acknowledge that natural sciences come from the CS / LW, as well both identify the same origin of the 'crisis' - as substitution of the world of quality for the world of quantity due to our forgetfulness [13, p. 48-50]. ${ }^{9}$ But the differences arise when it comes to the solution.

Differences in solution. Dewey claims that 'split' between CS and natural sciences can be solved only by finding out the unified method /

\footnotetext{
${ }^{7} \mathrm{CS}=$ common sense; LW $=$ life-world.

8 «The problem of the relation to the domain of common sense to that of science has notoriously taken the form of opposition of the quantitative to the non-quantitative; largely, but not exclusively, the quantitative» [8, p. 71].

9 «Science takes its departure from common sense, but the return road into common sense is devious and blocked by existing social conditions» [8, p. 83].
} 
logic / pattern of inquiry as common to both common sense (the lifeworld) and the natural sciences. Thus, the gap between the two is caused not because of the differences between the methods, but by the problems they are dealing with. Therefore, finding out the unified method or pattern of inquiry must serve as the only solution [8, p. 84].

Husserl, in his turn, thought that the difference is not just of the subject-matter, but of the methods, and thus, wanted to ground the lifeworld (the common sense) into phenomenology (as opposed to mathematical, but still eidetic method) to that of natural sciences.

In other words, Dewey wants to find the unified meta-language to properly deal with both the life-world and the natural sciences, whereas Husserl thinks that basically there are two: phenomenology and the natural sciences, which are opposed to each other.

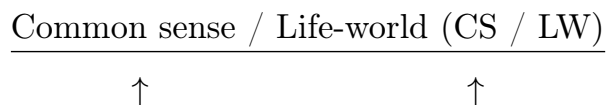

Method of phenomenology Method of Natural sciences $=$

Two meta-languages to describe and deal with one CS / LW

Husserl's way: to ground CS / LW into transcendental phenomenology, because natural sciences are not adequate to properly describe and deal with the former.

Dewey's way: to close the gap ('crisis') between CS / LW and natural sciences one has to find the general method (pattern) of natural sciences and to employ it in CS / LW. This method will be the unified logic of both CS / LW and that of natural sciences.

It is obvious that Dewey's and Husserl's ways of dealing with the 'crisis' are essentially opposed to each other. For Husserl, Dewey's way would be essentially naturalistic (naturalistic attitude), when for Dewey, Husserl's approach would present an appeal to some 'occult' intuition, with nothing scientific about it.

It's also true that both couldn't avoid the metaphysical foundations of their philosophies. In Husserl case, it is still Cartesianism (conceptually), while Dewey's metaphysical perspective is that of emergentism. (And it is also clear that for Dewey a crisis between transcendental phenomenology and natural sciences would be an absurd and the metaphysical atavism.) 
When Husserl looks at the natural sciences negatively (through their identification with physicalism), Dewey's outlook on them is much more positive and progressive, because namely from the natural sciences, the unified method should be extracted and employed into CS / LW, which would make our dealing with this qualitative realm successful, without any reduction to the natural sciences as such.

In general, it is interesting that both Dewey and Husserl identified the origin of the crisis between the life-world and the natural sciences very similarly, though Dewey seems to be more optimistic in terms of its solution.

Remark on the hard problem of consciousness from the perspective of the crisis between the LW / CS and the natural sciences. Prima facie, the hard problem of consciousness (see: [1], [2]) could be looked at more as a philosophical problem (as the heart of the contemporary mind-body problem), than that of the sciences. But one can look at the hard problem as genuinely the scientific problem in the first place. Originally, the hard problem can be stated like this: 'Why do we have conscious (or subjective) experience when it's logically possible not to have it at all?' 'Why aren't we zombies?'.

As predicated on the discussion above, we can formulate the hard problem in the following way (with no loss of the original meaning): 'Why are we living in the world of quality (the life-world), when it's logically possible that we could have lived in the world of pure quantity with no quality inside whatsoever (i.e., the zombie-world)?'.

In this formulation, the hard problem could also appear from the substitution of the life-world (common sense) with the world of science. Or in the other words, the world of quality was substituted with the world of quantity. According to Husserl and Dewey, science grows out of the life-world. It clarifies and deepens it. But when we have a dominion of the quantitative world over the qualitative, then it becomes logically possible to ask such a question: 'Why do we have quality in the first-place, when it's conceivable to have and live in the world of pure quantity (the zombie-world)?'.

Thus, the hard problem (as well as the crisis itself) seems to come out of the putting the horse in front of the cart: instead of acknowledging that science originates from the life-world (common sense) and grounding it there, one assumes the life-world itself is a byproduct of science itself, and therefore, comes out after, rather than before. In Dewey's words, the world of quality (as it is had) is substituted with the world of quantity (as it is known).

Therefore, the origins of the hard problem are the following: substi- 
tution of the LW / CS (thing-as had / the world-of-quality) with that of a pure science (things-as-known / the world-of-quantity) as stipulated by the progress of science and as based on our forgetfulness. If to show that quality objectively comes first, then the hard problem (as well as the crisis in question) ceases to exist.

\section{Pattern of inquiry / denotative method}

What is this 'common structure or pattern' of inquiry that could be applied in 'both common sense and science'? In his Logic, Dewey calls this the pattern of inquiry, and in Experience and Nature it is used by the name of denotative method. That being said, in this paper, I will use them interchangeably and show why it should be done so.

Before exploring Dewey's method properly, one has to mention the following. Dewey is always portrayed as an anti-rationalist and antiintellectualist. This is true, but only to some extent. At first, one has to clarify what Dewey usually meant under 'rationalism' in general. I'm eager to claim that by rationalism, Dewey understand the facts-ideas relation, when namely ideas come first, despite and often as opposed to the facts.

Rationalism (in a negative sense) is when facts are dependent upon ideas. When ideas determine facts. This usually leads to idealism, and thus this kind of rationalism could be called as idealistic rationalism. Schematically, it could be portrayed in this way:

idea $\rightarrow$ fact $\rightarrow$ idea.

That being said, it will be also wrong to view Dewey as anti-rational. In the very beginning of his Logic, Dewey is talking about rationality or reasonableness (as different from rationalism), and, by that, he understands the means-consequences relation. Where by 'means' one should understand the methods, when 'consequences' are the outcome of the application of the methods, - namely knowledge or better to say, 'warranted assertability'. For Dewey, «the general character of knowledge as an abstract term is determined by the nature of the methods used, not vice versa» $[8$, p. 19].

As opposed to rationalism, the main idea of instrumentalist rationality is that ideas should be controlled by facts, and not vice versa. Ideas are always subject to change, because facts are also subject to change in the first place, and not vice versa.

$$
\text { fact }^{1} \rightarrow \text { idea }^{1} \rightarrow \text { fact }^{2} \rightarrow \text { idea }^{2} \ldots \infty
$$


Logic is to be dependent on the sciences and not vice versa:

As the methods of the sciences improve, corresponding changes take place in logic [...]. [Again, logic is] naturalistic in the sense of the observability, in the ordinary sense of the word, of activities of inquiry. Conceptions derived from the mystical faculty of intuition or anything that is so occult as no not to be open to public inspection and verification (such as the purely psychical for example) are excluded [8, p. 21, 26].

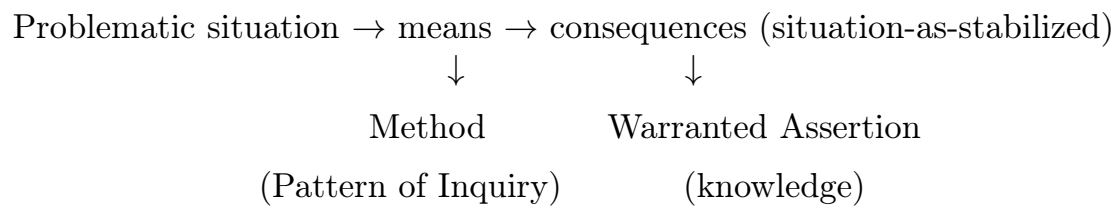

The reason, why Dewey preferred 'warranted assertion' to the knowledge is what Karl Popper would earlier call the falsification principle [19]:

In scientific inquiry, the criterion of what is taken to be settled, or to be knowledge, is being so settled that it is available as a resource in further inquiry; not being settled in such a way as not to be subject to revision in further inquiry [8, p. 16].

The inquiry starts with the problematic situation. The end of the inquiry should result with the situation as stabilized, with the warranted assertion (or knowledge) as the outcome. The method used is to be the means for the situation to be stabilized. Inquiry is successful when the end-asintended are fulfilled by the means used ${ }^{10}$.

Speaking phenomenologically, one can say that something is true, if the meaning-intention functions as a meaning-fulfillment, or if the 'means' functionally corresponds to 'ends'. In other words, $\mathrm{P}$ is true, if there's a functional correspondence between intention (P-as-intended) and its fulfillment (P-as-fulfilled (realized)). Therefore, this or that hypothesis / idea /theory is true when what it says, it actually does.

What is the scientific means, which Dewey finds so progressive and reliable?

The essential structure of the pattern of inquiry. It should be noted that inquiry is 'double-barreled"11, because genuinely it has two constituents:

10 «It is reasonable to search for and select the means that will, with the maximum probability, yield the consequences which are intended» $[8$, p. 17].

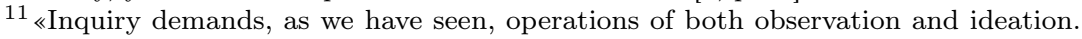
There would be no control of the proves of inquiry if each of these operations were not expressly formed with reference to the other» [8, p. 136]. 
(1) fact, primary experience (things-as- $h a d$ ), observation, perception; asymbolic matter;

(2) idea, meaning, hypothesis, theory, secondary experience (things-asknown); ideation; symbolic form.

The first cluster Dewey calls induction, whereas the second one is termed by deduction. Dewey suggests that there is always a 'double movement' to and from:

The movement toward suggestion or hypothesis and the movement back to facts [...] the movement toward building up the idea is known as inductive discovery (induction, for short); the movement toward developing, applying, and testing, as deductive proof (deduction, for short) [5, p. 64-65].

Facts should be in a functional correspondence with ideas. Dewey's pattern of inquiry could be portrayed in the following way:

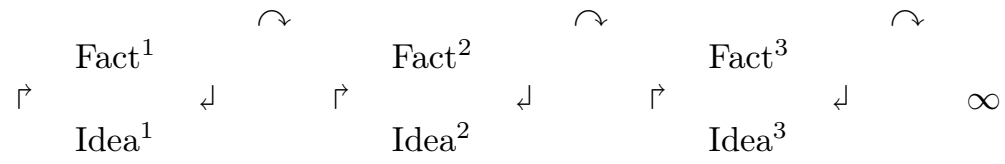

Therefore, to transform an indeterminate situation into a determinate one, one has to use the above-mentioned pattern or method. That is, there should be a functional correspondence between facts and ideas, which is signified by the following operators $\lceil\downarrow$. When the situation (the contextual whole) is changed, the facts are also to be changed, which leads to the changes of ideas, which are to be predicated on facts. The latter is signified by this operator: $\curvearrowright$. Since, situation is always subject to change (due to evolution as the fundamental principle of the Universe) [3], this process will go on forever, which is signified by this symbol $\infty$.

Dewey's denotative method as it is portrayed in his Experience and Nature, has no difference from the pattern mentioned-above, but we can say some more about it to clarify the things better.

Every 'experience' appears as a 'cluster' of the primary and secondary experiences. The former signifies things-as- had (or experienced-as) [4], the latter points to the things-as-known. So, we always start with primary experience, form on its basis the secondary experience and then go back to the primary experience in order to test the secondary one. Again, this is the same 'to and from' movement as specified above. ${ }^{12}$ Schematically, it can

12 «That the subject-matter of primary experience sets the problems and furnishes the first data of the reflection which constructs the secondary objects is evident; it is also obvious that test and verification of the latter is secured only by return to things 
be put like this (where experience ${ }^{1} \rightarrow$ experience $^{2} \rightarrow$ experience $^{3}$ should be understood as predicated on situation ${ }^{1} \rightarrow$ situation $^{2} \rightarrow$ situation $^{3}$ an so on):

\begin{tabular}{|c|c|c|c|c|c|}
\hline $\begin{array}{c}\text { experience }^{1} \\
= \\
\text { primary }^{1}\end{array}$ & $\rightarrow$ & $\begin{array}{c}\text { experience }^{2} \\
= \\
\text { primary }^{2}\end{array}$ & $\rightarrow$ & $\begin{array}{c}\text { experience }^{3} \\
= \\
\text { primary }^{3}\end{array}$ & $\begin{array}{l}\rightarrow \\
=\end{array}$ \\
\hline secondary ${ }^{1}$ & $\rightarrow$ & $\begin{array}{l}\risingdotseq \\
\text { secondary }\end{array}$ & $\rightarrow$ & $\begin{array}{ll}\Gamma & ل \\
\text { secondary }\end{array}$ & $\rightarrow$ \\
\hline
\end{tabular}

Thus, 'experience' means a 'cluster' of primary (facts) and secondary (ideas) experiences, which gives rise to another one, and the latter to another one, and this process goes on forever, due to a continuity between them as well as interaction ${ }^{13}$ between each other, as well as with their environments. Continuity also prevents this or that cluster to become fixed and institutionalized. Whereas, the principle of interaction invites current experience to influence the future ones, as well as for the latter to borrow something from the former.

To sum up, one can definitely say that not only the pattern of scientific inquiry and the denotative method refer to essentially the same method, but even more - one can suggest that experience and inquiry are basically the same as well. Inquiry is experiential: we start with a qualitative situation (which grounds the objects of primary experience), with the things-as- $h a d$ and test our hypotheses (secondary experience) through going back to where we started. On the other hand, experience as such is an inquiry, because we always deal with problematic situations (when 'something happens') [7, p. 13]. Namely the latter points to the fact that our experiences are precarious and that, to survive and function well, we are trying to transform the indeterminate situation into determinate one, which signify our experience as stable. Due to our always changing environment and situations, we essentially oscillate between the precariousness and stableness of our experience. Thus, we always inquire into the past, future and present. I think, Dewey would definitely agree with Karl Popper in that 'all life is problem-solving'. Experience is inquiry; inquiry is life.

of crude or macroscopic experience the sun, earth, plants and animals of common, every-day life. But just what role do the objects attained in reflection play? Where do they come in? They explain the primary objects, they enable us to grasp them with understanding, instead of just having sense-contact with them» [7, p. 16].

${ }^{13}$ This principle «assigns equal rights to both factors in experience - objective and internal conditions. Taken together, or in their interaction, they form what we call a situation» [15, p. 518]. 
We live through inquiry, because life is inquiry. Thus, we are doomed to learning, development and growing as people. Life with no inquiry is not life at all. It is simply death.

Remark on experience as aesthetic $^{14}$. It will not be a mistake to say that Dewey is a philosopher of science in a very wide sense, and namely scientific method (the pattern of inquiry) is what Dewey applied in all areas of philosophy he was dealing with. And aesthetics is not an exception here. It was another area in which he employed his method.

When is experience consummatory? Let's recall the way I interpreted 'experience', i.e., as a cluster of primary and secondary experiences, which gives rise to another cluster and so on (due to the principles of continuity and interaction). Now, let's look at that cluster closer. Thus, it consists of the primary and secondary stuff, and it is necessary that it should be a functional correspondence between them. That being said, when does aesthetic feeling arise? I think, it is a byproduct if the above-mentioned functional correspondence does happen! Then it could be a feeling of delight when it does, when it works!

In his Logic, Dewey seems to support such a conclusion:

The words beauty, elegance, show clearly that here is a case of appreciation. Even slight analysis of the passage shows that the theory is elegant and has beauty because its subject-matter presents a consummated harmonious ordering of diverse facts and conceptions. Intellectual activity, science, has its phases of appreciation as truly as have the fine arts. They arise whenever inquiry has reached a close that fulfils the activities and conditions which led up to it. Without these phases, sometimes intense, no inquirer would have the experiential sign that his inquiry had reached its close. $^{15}[\ldots]$ The occurrence of these judgments of completion, not different in kind from those ordinarily called aesthetic, constitutes a series of landmarks in the progress of any undertaking. They are signs of the achieved coherence of factual material and the consistency of conceptual material [8, p. 178]. ${ }^{16}$

\footnotetext{
${ }^{14}$ This reflection is based on the reading from [15, p. 525-574] on Dewey's Aesthetics (chapters 33, 34, 35).

15 «Words such as climax, peak, culmination, refer to consummatory objects» $[8$, p. 177].

${ }^{16}$ In his Experience and Nature, Dewey seems to express the same conclusion: «The idea that meanings are originally floating and aesthetic and become intellectual, or practical and cognitive, by a conjunction of happy accidents, puts the cart before the horse. Its element of truth is that there is a genuine distinction between having a meaning and using it; the element of falsity is in supposing that meanings, ideas, are first had and afterwards used. It required long experience to enforce recognition of the distinction; for originally any meaning had, is had in and for use. To hold an idea contemplatively and aesthetically is a late achievement in civilization» [7, p. 220].
} 


\section{Dewey, Popper and the method of natural sciences: what comes first, hypothesis or fact?}

One can say that Dewey insists on the 'objective' state of affairs: that namely objective facts (objective situation) lead us to come up with hypotheses do cope with the former; that these hypotheses are not idealistic (i.e., with no facts as backing them up). In other words, if there are no facts, there is no need for hypotheses as such. Namely that's why Dewey insists on the induction (when facts via observation bear hypotheses) as the first step of the scientific method, which is followed by deduction (as experimental testing of the hypotheses on facts). Induction: [facts $\rightarrow$ hypotheses]; deduction: [hypotheses $\rightarrow$ facts]. It's obvious that together they constitute denotative method or pattern of inquiry (which is a functional correspondence of them) [8, p. 423, 428]. On the other hand, Dewey does agree that to deal with facts as facts (via experimental observation $)^{17}$, one does need ideas / conceptions / hypotheses beforehand too ${ }^{18}$. We do need ideas to specify facts from the contextual whole (situation) ${ }^{19}$. That's why he treats his method as hypothetical-deductive as well. One could suggest that what stops him from accepting this naming entirely is his worry that if we start to emphasize hypotheses at first, we could end up with idealistic doctrines (ideas - facts - ideas), with no facts as the foundation ${ }^{20}$.

Karl Popper, on the other hand, is the one who proposed the hypothetical-deductive method, or a deductive-method of testing [18]. To some extent, Popper looks more at the 'subjective' or 'epistemological' side of the same method [17, p. 136], while insisting that we already start with hypotheses. In this sense, Popper starts where Dewey would put just a footnote: that is to cope with facts as facts, we need ideas (as hypotheses) at first. 'Subjectively', we do need 'secondary experience' to specify and identify

17 «Observations formed by variation of conditions on the basis of some idea or theory constitute experiment» [5, p. 298].

${ }^{18}$ Induction as such means the preparation of the material of perception for the further testing, but the very process of this preparation should be already governed by conceptions / hypotheses / ideas: «the operations that prepare the material must be so directed by ideas (as hypotheses), as to satisfy, conjunctively and disjunctively, the functions of affirmation-negation» [8, p. 427]. «The operations of experimental observation which prepares standardized materials need direction by conceptions» [8, p. 428].

19 «The development in discourse of the directive conception that is involved provides the sole variable material for identifying the deductive phase of scientific method» $[8$, p. 428].

${ }^{20}$ In general, for Dewey, hypothetical deductive-method is rather an intermediate stage of inquiry' [8, p. 423-424]. 
the 'primary experience' from the contextual whole (situation). Otherwise, it would be impossible to look at this or that event as 'fact' - it would be just a pure 'had'21.

In this sense, we can say that Dewey's and Popper's understanding of the scientific method is genuinely the same; the only difference being one of emphasis. Thus, both would agree that facts exist indeed objectively prior to our making hypotheses to test them, but before we do the latter, these are just potentially facts: they need to be specified from the contextual whole of the situation.

An idea of an end to be reached, an end-in-view, is logically indispensable in discrimination of existential material as the evidential and testing facts of the case. Without it, there is no guide for observation; without it, one can have no conception of what one should look for or even is looking for. One 'fact' would be just as good as another-that is, good for nothing in control of inquiry and formation and in settlement of a problem [8, p. 491].

Therefore, events are to be looked as facts, when the initial hypotheses are applied to them. Only then they became real facts.

A generalization in the form of a hypothesis is a prerequisite condition of selection and ordering of material as facts. A generalization is quite as much an antecedent of observation and assemblage of facts as it is a consequence of observing and assembling them. Or, more correctly stated, no generalization can emerge as a warranted conclusion unless a generalization in the form of a hypothesis has previously exercised control of the operations of discriminative selection and (synthetic) ordering of material to form the facts of and for a problem [8, p. 491-492].

Scientific method begins when we start experimentally applying the secondary experience (hypotheses) to the primary one (existential matters) ${ }^{22}$. Other than that, we are still at the common sense (prescientific) level of existence ${ }^{23}$.

$21 \ll[\ldots]$ without a problem, no observation» $[18$, p. 6$]$.

22 «To return to the point suggested earlier: what scientific inquirers $d o$, as distinct from what they say, is to execute certain operations of experimentation - which are operations of doing and making that modify antecedently given existential conditions so that the results of the transformation are facts which are relevant and weighty in solution of a given problem. Operations of experimentation are cases of blind trial and error which at best only succeed in suggesting a hypothesis to be later tried except as they are themselves directed by a hypothesis about a solution» [8, p. 492]

$23 \ll$ Nothing so fatal to science can be imagined as elimination of experimentation, and experimentation is a form of doing and making. Application of conceptions and hypotheses to existential matters through the medium of doing and making is an intrinsic constituent of scientific method» [8, p. 434-435]. 
That being said, if to 'reconcile' the differences between the emphases, one could say that their methods are initially the same. The following scheme could clarify what was said before.

(1) Problematic situation

(problematic contextual whole;

potential facts and primary experience)

$\uparrow$

(2) Initial hypothesis

(secondary experience) $\rightarrow \quad$ (3) facts (primary experience) (application of initial hypothesis)

\section{$\downarrow$}

$\rightarrow \quad$ (4) conclusive hypothesis (secondary experience)

The problematic situation comes first. In order to distinguish facts from it, we need initial hypotheses. After testing it, we come up with the conclusive hypothesis and identify facts as facts. Namely, with the application of the secondary experience, we identify primary experience as primary (i.e., what led us to the secondary experience). But if there was no secondary experience before, there would be no possibility to identify the primary experience as such. If to look at the scheme above-mentioned, Dewey starts emphasizing scientific method as scientific with steps (1), (3) and (4) (while also acknowledging that (2)) also takes place, but usually omitting it); when Popper thinks that genuine science starts with the application of (2) to (1) (also stating that (1) precedes (2)).

Thus, both agree with (1) as the objective start, but the place where they disagree is the emphasis in the same process.

The method, which could suite to both Dewey and Popper $^{24}$ (if to eliminate the differences in the emphases) would be the following:

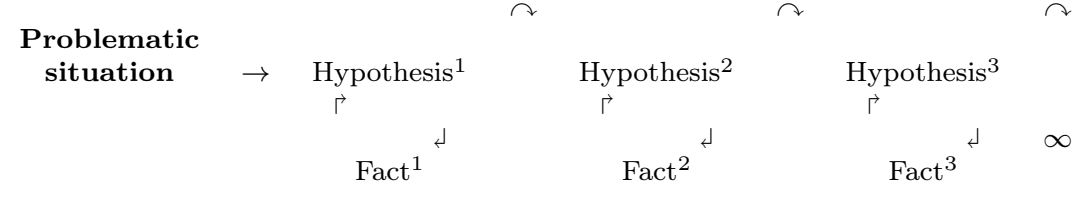

Since, Popper was starting with deduction, and Dewey, in his turn, did acknowledge that hypotheses come before facts (which is deduction in Popper's sense), both Dewey's and Popper's scientific methods could be

${ }^{24}$ Popper's article The Logic and Evolution of Scientific Discovery could serve as a good example of a problem situation as a start of inquiry [18, p. 3-22]. 
called hypothetic-deductive method ${ }^{25}$. Paradoxically, what Dewey called 'induction' was basically deduction in Popper's sense.

Prima facie, it seems there's more divergence in Dewey's and Popper's views on scientific method. But after further clarification, the situation changes and convergence becomes more visible on the horizon.

Remark on Dewey's and Popper's methods and philosophy of mind. Does Dewey's emphasis on induction (facts $\rightarrow$ hypotheses), rather than deduction (hypotheses $\rightarrow$ facts), stem from his behavioristic emergentism (that instead of mind / consciousness / self, what arises is the life-behavior)?

Dewey always emphasizes something as 'taken', 'acted upon', and not just 'given' ${ }^{26}$. Indeed, he's very critical of any kind of purely firstperson attitude toward knowledge. Even his notion of 'primary experience' (something as 'had'), which prima facie resembles the phenomenological 'givenness' is an appeal to the 'had' again as publicly observable and has nothing to do with the first-person experience, on which the phenomenological tradition is built. To put it shortly, Dewey's perspective when looking at experience is third-person, and is sharply opposed to the first-person one.

As it was mentioned before, the activity of an organism comes from the functional correspondence between fact (perception) and idea (concept) with no tertium quid as an ego or self. But here arises the question: if the organism's self is eliminated, where does this organism's motivation come from? Why does a human organism have to act upon namely this fact and this stimulus as opposed to the other? It seems that Dewey's thirdperson perspective and functionalism leaves this question open. Since, self is eliminated, Dewey's emphasis on facts (as objective states of affairs), rather than hypotheses, which come from the 'subjective' aspect of an organism, can suggest why Dewey's appeal to induction is so emphasi-

${ }^{25}$ In his letter to Max Otto from 25 January 1929, Dewey writes very clearly as regarding his denotative method as expressed in Chapter 1 of his Experience and Nature: «What I meant - only didn't know it - was that reflective analysis \& its products form a method for leading back to the subjectmatter of direct or 'gross' experience; so that the former designates or denotes a path \& projects a goal to be found in the latter - which being illuminated, clarified \& directed by reflective findings as method, also tests and checks the latter» [7, p. 408].

26 «That which is 'given' in the strict sense of the word 'given', is the total field of situation. [...] In the strict sense, it is taken rather than given» [8, p. 127]. «Objects and qualities as they naturally present themselves or as they are 'given', are not only not the data of science but constitute the most direct and important obstacle to formation of those ideas and hypotheses that are generally relevant and effective» [8, p. 421]. 
zed: elimination of subjectivity, and the constant emphasis on objectivity (as something publicly observable, - be it problematic situation, facts, primary experience etc.), due to his orientation on the natural scientific method and caution against idealism and any kind of supernaturalism could lead Dewey to looking at this objectivity as primary scientific matter, while making hypotheses the secondary one.

Popper's philosophy of mind was that of interactionism. For Popper, self indeed existed, and it was not reducible to the brain or behavior either. In Popper's words, World 2 (mind / consciousness / self) was not to be reducible and identified with World 1 (brain, behavior or any physical state).

\section{Acknowledgements}

I am very grateful to Larry Hickman, Teed Rockwell, Dave Denneny and especially to Dave Gray for great comments and discussion. I am also grateful to Kenneth Stikkers for a fruitful discussion in Dewey class in person and especially online (SIUC, Spring 2020), which made this paper possible in the first place.

\section{References}

[1] Chalmers D. Facing up to the Problem of Consciousness // Journal of Consciousness Studies. - 1995. - Vol. 2 (3). - P. 200-219.

[2] Chalmers D. The Conscious Mind: In Search of a Fundamental Theory. - New York: Oxford University Press, 1996.

[3] Dewey J. Evolution and Ethics. In: Hickman L.A., Alexander T.M. The Essential Dewey. - Bloomington and Indianapolis: Indiana University Press, 1998. - Vol. 2. Ethics, Logic, Psychology. - P. 225-235.

[4] Dewey J. The Postulate of Immediate Empiricism // Hickman L.A., Alexander T.M. The Essential Dewey. - Bloomington and Indianapolis: Indiana University Press, 1998. - Vol.1. Pragmatism, Education, Democracy. - P. 115-120.

[5] Dewey J. How we think. The Middle Works, 1899-1924. - Vol.6: 1910-1911. - Southern Illinois University Press, 1978. 
[6] Dewey J. Reconstruction in Philosophy. The Middle Works, 18991924. - Vol. 12: 1920. — Southern Illinois University Press, 2008.

[7] Dewey J. Experience and Nature. The Later Works, 1925-1953. Vol. 1: 1925.- Southern Illinois University Press, 2008.

[8] Dewey J. Logic: The Theory of Inquiry. The Later Works, 1925-1953. - Vol. 12: 1938. - Southern Illinois University Press, 2008.

[9] Dewey J. Propositions, Warranted Assertibility, and Truth // Hickman L.A., Alexander T.M. The Essential Dewey. - Bloomington and Indianapolis: Indiana University Press, 1998. - Vol.2. Ethics, Logic, Psychology. - P. 201-212.

[10] Dewey J. Anti-Naturalism in Extremis // Hickman L.A., Alexander T.M. The Essential Dewey. - Bloomington and Indianapolis: Indiana University Press, 1998. - Vol. 1. Pragmatism, Education, Democracy. - P. 162-172.

[11] Hickman L.A., Alexander T.M. The Essential Dewey. - Bloomington and Indianapolis: Indiana University Press. - Vol.1. Pragmatism, Education, Democracy.

[12] Hickman L.A., Alexander T.M. The Essential Dewey. - Bloomington and Indianapolis: Indiana University Press. - Vol. 2. Ethics, Logic, Psychology.

[13] Husserl E. The Crisis of European Sciences and Transcendental Phenomenology. An Introduction to Phenomenological Philosophy / Translated by David Carr. - Evanston: Northwestern University Press, 1970.

[14] Leonov A. The mind-body problem(s) in Descartes' "Meditations" and Husserl's "Crisis" (Part 1) // Filosofska dumka. - 2020. - Vol. 4. P. 91-100. https://doi.org/10.15407/fd2020.04.091

[15] McDermott J.J. The Philosophy of John Dewey. Two Volumes in One. 1. The Structure of Experience. 2. The Lived Experience. - The University of Chicago Press, 1982.

[16] O'Connor T., Wong Hong Yu. Emergent Properties. Stanford Encyclopedia of Philosophy [Electronic source]. - Available at: https://plato.stanford.edu/entries/properties-emergent/ 
[17] Popper K. Scientific Method // Miller David (ed.). Popper Selections. - Princeton University Press Princeton, New Jersey, 1985.

[18] Popper K. The Logic and Evolution of Scientific Theory // Popper Karl. All Life is Problem Solving. - Routledge, 2007.

[19] Popper K. The Logic of Scientific Discovery. - London and New York: Routledge, 2002.

Надійшла до редакчії 31 липня 2020 р.

\section{Леонов Андрій Юрійович}

Кафедра філософії

Школа гуманітарних наук

Університет Райса

Г'юстон, Техас 77251-1892

США

\section{Leonov Andrii}

Department of Philosophy

School of Humanities

Rice University

Houston, Texas 77251-1892

USA

(iD https://orcid.org/0000-0002-4174-9734

(a)

andrii.leonov@rice.edu

10.31812/apd.v0i21.4369 